\title{
A community based study to determine incidence of cervical cancer and willingness of women to participate in cervical cancer screening program in Navsari, Gujarat, India
}

\author{
Parth H. Vyas ${ }^{1 *}$, Kanchan Dhadwe ${ }^{2}$, Harsha A. Shah ${ }^{2}$, Hiral M. Dave ${ }^{1}$, Ashwin A. Shah ${ }^{3}$
}

\begin{abstract}
${ }^{1}$ Department of Community Health, Gram Seva Trust Sarvajanik Hospital, Kharel, Navsari, Gujarat, India ${ }^{2}$ Department of Obstetrics and Gynecology, Gram Seva Trust Sarvajanik Hospital, Kharel, Navsari, Gujarat, India ${ }^{3}$ Department of Medicine, Gram Seva Trust Sarvajanik Hospital, Kharel, Navsari, Gujarat, India
\end{abstract}

Received: 11 July 2019

Accepted: 30 August 2019

\author{
*Correspondence: \\ Dr. Parth H. Vyas, \\ E-mail: gstkharel@yahoo.com
}

Copyright: (C) the author(s), publisher and licensee Medip Academy. This is an open-access article distributed under the terms of the Creative Commons Attribution Non-Commercial License, which permits unrestricted non-commercial use, distribution, and reproduction in any medium, provided the original work is properly cited.

\begin{abstract}
Background: Carcinoma of the uterine cervix is a major health problem faced by the Indian women. Regular cervical cytological examination by all sexually active women can prevent the occurrence of carcinoma cervix. Early detection of cervical cancer is possible with Pap smear tests.

Methods: Women above 25 years of age, living in study area and want to participate in study were included. Total 2352 women were enrolled in study. House to house visits were conducted in all the village area by using simple random sampling method. Information about cervical cancer was given. Pap test for cervical cancer screening was carried out by gynaecologist. Cytological examination and confirmation was done by pathologists.

Results: A total of 3001 women had attended village level IEC session and out that, 2352 (78.4\%) women took part in the screening program. Out of these 2352 women, 2007 women ( $85.3 \%$ compliance) had given consent for physical cervical examination and Pap smear. The incidence of cervical cancer was $0.2 \%$ on the basis of clinical examination and biopsy.

Conclusions: Higher compliance for undergoing vaginal examination and Pap test shows the positive health seeking behaviour of the women but for that, strong IEC and sensitization about the disease must be done to improve the participation. Sensitivity of Pap test was poor and couldn't find true positive cases.
\end{abstract}

Keywords: Biopsy, Compliance, Cervical cancer, Incidence, Pap test, Screening

\section{INTRODUCTION}

Carcinoma of the uterine cervix is a major health problem faced by the Indian women, and every year, approximately 120,000 women develop this disease. ${ }^{1}$ India accounts for 15.2 per cent of the total cervical cancer deaths in the world. ${ }^{2}$ Although the incidence of carcinoma cervix has declined in the urban population, in the rural areas it continues to be highly prevalent. ${ }^{3}$
Regular cervical cytological examination by all sexually active women can prevent the occurrence of carcinoma cervix. ${ }^{4}$ Early detection of cervical cancer is possible with Pap smear tests. The proportion of women who undergo Pap smear testing ranges from $68 \%$ to $84 \%$ in developed countries as compared to India where the rates range from $2.6 \%$ to $6.9 \%$ among women in communities. ${ }^{5-8}$ Human Papilloma Virus (HPV) is proven to be a necessary but not sufficient cause of cervical cancer. The 
risk factors known to increase the incidence of cervical cancer are age, low socio-economic status, poor personal hygiene, lack of education, multiple sexual partners, early marriage, early child birth, higher parity and long-term use of hormonal contraceptive. ${ }^{9}$ A leading study from Canada revealed that the disease in the in situ stage (CIN III), on an average takes about 10-12 years to enter in the invasive stage i.e. the time gap between detectable pre clinical phase and the clinical phase is quite long so that it provides enough opportunity to administer management when complete cure is possible. ${ }^{10}$ Hence it is justified to keep the cervical cancer as one of the priority areas for cancer control activities.

\section{METHODS}

The present community based cross sectional analytical study was carried out from 1st April 2018 to 31st March 2019 with the objectives to determine willingness of women to participate in such kind of screening procedure and to determine incidence of Cervical Cancer amongst women residing in the study area. 28 Villages which are the field practice area of Gram Seva Trust, Kharel Hospital, District - Navsari were included. Women above 25 years of age and wanted to participate in screening program were included. Women who didn't give consent to participate in study were excluded. The consenting participants who satisfied the inclusion and exclusion criteria were enrolled in the study. Taking into account all such factors of feasibility the total sample size obtained was 2352. A semi-structured questionnaire was prepared in accordance with the study objectives. Data entry was done using Microsoft excel software 2010 version. Analysis of data was done by using SPSS version 20 software. Percentage analysis was done for socio demographic factors. Statistical tools like means, proportions were used appropriately. Study was divided in to 4 phases for better results and good understanding of the participants.

In 1 st phase by using simple random sampling method, house to house visits were conducted in all the village area and IEC meetings at the convenient place were organized by the supervisors of the institute with the help of field level workers. In 2nd phase health talk was delivered at these meetings and information on risk factors, signs, symptoms, complications, precautions to be taken and steps to prevent Cervical cancer was given. A part from health talk women were also informed about screening camp at their village's Primary Heath Center on specified date. In the $3^{\text {rd }}$ phase, after explaining the procedure and taking informed consent, pelvic examination and Pap test for cervical cancer screening was carried out by gynecologist. Cytological examination of slides and confirmation was done by pathologists.

In $4^{\text {th }}$ phase, women who had any complain were referred to Gram Seva Trust sarvajanik hospital, Kharel for further management. Detail history of the patients was taken. Thorough pelvic examination was done.

\section{Pelvic examination}

- Inspection of the vulva for any lesion or discharge

- Vagina, cervix and fornices were inspected for appearance of cervix, any erosion, ulcer, growth, any discharge and bleeding during physical examination.

\section{RESULTS}

A total of 3001 women had attended village level IEC session and out that, 2352 (78.4\% compliance) women took part in our screening program. Out of which $31 \%$ belonged to the age group of 36 to 45 years, $27.7 \%$ belonged to $25-35$ years of age and $21.1 \%$ of women belonged to 45-55 years of age. According to the modified Kuppuswamy socioeconomic scale, $80.9 \%$ of the study population belonged to the upper lower class, $10.6 \%$ to lower class, $7 \%$ to the lower middle class and $1.5 \%$ belonged to the upper middle class. The literacy profile showed $27.5 \%$ illiterate while $32.6 \%$ having a primary education, $23.5 \%$ having secondary education, $10.7 \%$ had studied up to higher secondary, $5.4 \%$ were graduated.

\section{Table 1: Socio demographic profile of study population.}

\begin{tabular}{|c|c|c|c|}
\hline & & $\begin{array}{l}\text { No. of } \\
\text { respondents }\end{array}$ & Percentage \\
\hline \multirow{6}{*}{$\begin{array}{l}\text { Age } \\
\text { (in years) }\end{array}$} & $<25$ & 76 & $3.2 \%$ \\
\hline & $25-35$ & 651 & $27.7 \%$ \\
\hline & $36-45$ & 729 & $31.0 \%$ \\
\hline & $46-55$ & 496 & $21.1 \%$ \\
\hline & $56-65$ & 321 & $13.7 \%$ \\
\hline & $>65$ & 78 & $3.3 \%$ \\
\hline \multirow{5}{*}{ Occupation } & Business & 11 & $4.7 \%$ \\
\hline & Farming & 1160 & $49.7 \%$ \\
\hline & Homemaker & 1082 & $46.3 \%$ \\
\hline & Job & 78 & $3.3 \%$ \\
\hline & Student & 3 & $0.1 \%$ \\
\hline \multirow{5}{*}{ Education } & Graduate & 124 & $5.4 \%$ \\
\hline & $\begin{array}{l}\text { Higher } \\
\text { secondary }\end{array}$ & 246 & $10.7 \%$ \\
\hline & Secondary & 537 & $23.5 \%$ \\
\hline & Primary & 743 & $32.6 \%$ \\
\hline & Illitarate & 629 & $27.5 \%$ \\
\hline \multirow{4}{*}{$\begin{array}{l}\text { Marital } \\
\text { status }\end{array}$} & Married & 1879 & $83.5 \%$ \\
\hline & Widow & 338 & $15.0 \%$ \\
\hline & Unmarried & 18 & $0.8 \%$ \\
\hline & Divorce & 14 & $0.6 \%$ \\
\hline \multirow{4}{*}{$\begin{array}{l}\text { Socio } \\
\text { economic } \\
\text { status }\end{array}$} & Lower & 218 & $10.6 \%$ \\
\hline & $\begin{array}{l}\text { Lower } \\
\text { middle }\end{array}$ & 144 & $7.0 \%$ \\
\hline & $\begin{array}{l}\text { Upper } \\
\text { lower }\end{array}$ & 1655 & $80.9 \%$ \\
\hline & $\begin{array}{l}\text { Upper } \\
\text { middle }\end{array}$ & 30 & $1.5 \%$ \\
\hline
\end{tabular}


Majority i.e. $49.7 \%$ among the study participants were engaged in farm labour and $46.3 \%$ were housewives, $4.7 \%$ women were doing some sort of business, $3.3 \%$ were doing job and $0.1 \%$ were studying. Most of the women were married $(83.5 \%)$ with others being widowed (15\%), unmarried (0.8\%) and divorced (0.6\%). 17.6\% women got married before the age of 18 years and the maximum age at marriage was 35 years. $30.6 \%$ had a parity of 3 or more children (Table 1).

Table 2: Compliance of women attending screening camps.

\begin{tabular}{|lll|}
\hline Indicator & Number & Compliance \\
\hline $\begin{array}{l}\text { Total women attended } \\
\text { village meetings }\end{array}$ & 3001 & \\
\hline $\begin{array}{l}\text { Total women attended } \\
\text { screening camps }\end{array}$ & 2352 & $78.4 \%$ \\
\hline Total Pap smear taken & 2007 & $85.3 \%$ \\
\hline
\end{tabular}

Table 3: Results of Pap test and history of vaginal discharge.

\begin{tabular}{|c|c|c|c|}
\hline & & $\begin{array}{l}\text { No. of } \\
\text { Respondents }\end{array}$ & Percentage \\
\hline \multirow{3}{*}{$\begin{array}{l}\text { Pap test } \\
\text { results } \\
\text { (Total } \\
\text { 2007) }\end{array}$} & $\begin{array}{l}\text { Negative } \\
\text { (NILM) }\end{array}$ & 1828 & $91.1 \%$ \\
\hline & $\begin{array}{l}\text { Repeat the } \\
\text { test }\end{array}$ & 155 & $7.7 \%$ \\
\hline & $\begin{array}{l}\text { Atrophic } \\
\text { changes }\end{array}$ & 24 & $1.2 \%$ \\
\hline \multirow{2}{*}{$\begin{array}{l}\text { Women } \\
\text { with } \\
\text { complain } \\
\text { of vaginal } \\
\text { discharge }\end{array}$} & No & 1781 & $75.7 \%$ \\
\hline & Yes & 571 & $24.3 \%$ \\
\hline \multirow{6}{*}{$\begin{array}{l}\text { Type of } \\
\text { vaginal } \\
\text { discharge }\end{array}$} & Bloody & 7 & $1.2 \%$ \\
\hline & Curdy & 118 & $20.7 \%$ \\
\hline & $\begin{array}{l}\text { Foul } \\
\text { smelling }\end{array}$ & 60 & $10.5 \%$ \\
\hline & Others & 2 & $0.4 \%$ \\
\hline & Watery & 366 & $64.1 \%$ \\
\hline & Yellowish & 18 & $3.1 \%$ \\
\hline
\end{tabular}

Out of 2352 women, 2007 women ( $85.3 \%$ compliance) had given consent for physical cervical examination and Pap smear (Table 2). 571 (24.3\%) women complained of vaginal discharge. After asking about the nature of discharge $64.1 \%$ had watery discharge while $20.7 \%$ had curdy, $10.5 \%$ had foul smelling, 3.1\% had Yellowish, $1.2 \%$ had bloody and $0.4 \%$ had other type of discharge. $1.1 \%$ women had history of discharge of blood after sexual intercourse.

Among 2007 Pap smear taken, 1828 (91.1\%) results were Negative for Intraepithelial Lesions or Malignancy (NILM), 24 (1.2\%) slides had atrophic changes and 155 $(7.7 \%)$ slides required to repeat the test. None of the slide had positive carcinomatous changes. But 4 women were found to have cervical carcinoma on the basis of clinical examination and biopsy (Table 3 ).

In present study the Incidence of cervical cancer was 4 out of $2007(0.2 \%)$ women screened.

\section{DISCUSSION}

In present study the compliance and willingness of undergoing Cervical examination and Pap test was $85.3 \%$ while in Patra S et al study, $24.1 \%$ women were willing to go for pap test examination. ${ }^{11}$ In contrary to that $78.8 \%$ compliance was seen in Bhagwan $\mathrm{N}$ et al study. ${ }^{12}$ And $94.6 \%$ women had undergone pap test examination in Sherpa A et al study. ${ }^{13}$ According to WHO one of the requirements of successful screening program is to ensure high levels of coverage ( $80 \%$ or more) of the target population to be screened. ${ }^{14}$ In study done by Aswathy et al, screening programs met with low rates of compliance i.e. $6.9 \%$, due to many factors like stigma associated with the screening process, fear of procedure, lack of awareness, etc. and reported that appropriate knowledge on cervical cancer was a critical element in determining whether women would undergo a Pap test or not. ${ }^{8}$ However no such issues were faced in present study. In initial camps the number of women attending screening camp was low therefore extensive village level IEC meetings and sensitization about the diseases were held and overall higher compliance rate was might be due to these activity. Thus we can say that IEC and Sensitization plays an important role in cervical screening program.

In present study, $17.6 \%$ women got married before the age of 18 years. Early marriage indicates the earlier onset of sexual activity and prolonged sexual life. Thus, more chances of HPV infection and higher incidence of cervical carcinoma. In the study related to age at marriage and cervical cancer incidence, Prabhakar AK et al concluded younger age of marriage is clearly a risk factor for carcinoma cervix. ${ }^{15}$ In the present study $30.6 \%$ had a parity of 3 or more children. A study by Muñoz $\mathrm{N}$ et al concluded high parity increases the risk of squamous-cell carcinoma of the cervix among HPV-positive women. ${ }^{16}$ Therefore, a general decline in parity might partly explain the reduction in cervical cancer, recently seen in many countries. In the study $24.6 \%$ women had complained of vaginal discharge. This can be attributed to poor genital hygiene and presence of sexually transmitted diseases (STDs). ${ }^{17}$ Some of the STDs may also act as precursors for cancer cervix, thus may require prompt treatment. ${ }^{18}$

In present study among 2007 Pap smear examination, 1828 $(91.1 \%)$ results were Negative for Intraepithelial Lesions or Malignancy (NILM), 24 (1.2\%) slides had atrophic changes and $155(7.7 \%)$ slides required to repeat the test. Surprisingly, none of the slide had dysplastic or positive carcinomatous changes. Similarly in Yasmin J et al study, there was no evidence of cervical dysplasia or cancer cervix among the screened population. ${ }^{19}$ However in the study 4 cases had carcinomatous changes and diagnosis of these 
cases was made on the basis of clinical examination done by gynaecologist and biopsy reports. In study done by Arun R et al the Pap smear positivity rate was $3.6 \% .^{20}$ While in Ramesh $\mathrm{N}$ et al study $7 \%$ of the women had dysplastic smears which was comparable to Shamima Y et al study and $12.7 \%$ prevalence was seen in Mhaske $\mathrm{M}$ et al study. ${ }^{21-23}$ While in Thumoju et al study $13.9 \%$ samples were having abnormal pap cytology. ${ }^{24}$ In Sharma et al study, $4.67 \%$ showed carcinoma in-situ and $1.4 \%$ showed high grade malignancy. ${ }^{25}$ On the basis of results in the study, it can be said that role of thorough clinical examination should be considered as $1^{\text {st }}$ line screening process as 4 NILM cases of Pap smear were diagnosed to have cervical malignancy.

\section{CONCLUSION}

Higher compliance for undergoing vaginal examination and Pap test shows the positive health seeking behaviour of the women but for that, strong IEC and sensitization about the disease must be done to improve the participation. Unlike other studies, sensitivity of Pap test was poor and couldn't find true positive cases. So, to overcome false negative cases it is recommended that screening must be done by a person trained to observe the physical cervical changes. In spite of being a preventable cancer with various screening modalities, the incidence of cervical cancer is very high in developing countries. The study recommends that such types of screening camps and programs must be held more frequently in order to curb the menace due to cervical cancer.

\section{ACKNOWLEDGMENTS}

Our organization is grateful to the Unified Healthcare for Rural Underserved, USA and Desai Foundation, USA for their guidance and financial support. We would also like to thank district health officials, (CDHO, RCHO, ADHO, THO) medical officers, and staff of all 4 Primary Health Centre (Dhanori, Tankal, Kangvai, Ranverikalla) of Navsari for their unconditional support and help.

Funding: Unified Healthcare for Rural Underserved, USA \& Desai Foundation, USA

Conflict of interest: None declared

Ethical approval: The study was approved by the Institutional Ethics Committee

\section{REFERENCES}

1. Jacob M. Information, education and communication: Corner stone for preventing cancer of the cervix. Indian J Med Res. 2012;136(2):182-4.

2. Ferlay J, Shin HR, Bray F, Forman D, Mathers C, Parkin DM. Estimates of worldwide burden of cancer in 2008. Int J Cancer. 2010;127(12):2893-917.

3. Srivastava AN, Misra JS, Srivastava S, Das BC, Gupta S. Cervical cancer screening in rural India: Status and current concepts. Indian J Med Res. 2018;148:687-96.
4. Takiar R, Nadayil D, Nandakumar A. Projections of number of cancer cases in India (2010-2020) by cancer groups. Asian Pac J Cancer Prev. 2010;11(4):1045-9.

5. Swan J, Breen N, Coates RJ, Rimer BK, Lee NC. Progress in cancer screening practices in the United States. Results from the 2000 national health interview survey. 2003;97(6):1528-40.

6. Harry TK, Felicia MS, Ngugen S. A needs assessment of barriers to cervical cancer screening in Vietnamese American health care providers. Californian J Health Promotion. 2006;4:146-56.

7. Gakidou E, Nordhagen S, Obermeyer Z. Coverage of cervical cancer screening in 57 countries: low average levels and large inequalities. PloS Med. 2008;5:132.

8. Aswathy S, Quereshi MA, Kurian B, Leelamoni K. Cervical cancer screening: current knowledge and practice among women in a rural population of Kerala, India. Indian J Med Res. 2012;136(2):205-10.

9. Sreedevi A, Javed R, Dinesh A. Epidemiology of cervical cancer with special focus on India. Int $\mathrm{J}$ Womens Health. 2015;7:405-14.

10. Walton RJ. Cervical cancer screening programmes. Epidemiology and natural history of carcinoma of cervix. Can Med Ass J. 1976;114:1-32.

11. Patra S, Upadhyay M, Chhabra P. Awareness of cervical cancer and willingness to participate in screening program: public health policy implications. J Can Res Ther. 2017;13:318-23.

12. Bhagwan N, Kasturi J, Silvina A, Surendra S, Atul B, Sanjay H, Richard M, Sylla M, Ketayun D, Rengaswamy S. Determinants of women's participation in cervical cancer screening trial, Maharashtra, India. Bull World Health Organ. 2007;85(4):264-72.

13. Sherpa A, Karki B, Sundby J, Nygard M, Franceschii S, Clifford G. Population based study of cervical cancer screening in Bharatpur, Nepal. J Manmohan Memorial Inst Health Sci. 2015;1(4):3-8.

14. World Health Organization. Cervical cancer screening in developing countries: report of a WHO consultation, 2002. Available at: https:// apps. who. int/ iris/ handle/10665/42544. Accessed on 28 May 2019.

15. Prabhakar AK, Menon GR. Age at marriage and cervical cancer incidence. Indian $\mathbf{J}$ Cancer. 1995;32:63-8.

16. Muñoz N, Bosch FX, Sanjosé S, Herrero R, Castellsagué X, Shah KV. Epidemiologic classification of human papillomavirus types associated with cervical cancer. New England J Med. 2003;348(6):518-27.

17. Desai M. An assessment of community based cancer screening program among Indian women using the anganwadi workers. $\mathbf{J}$ obstet Gynecol Ind. 2004:54:483-7.

18. World Health Organization. Cervical cancer screening programme managerial guidelines. Geneva: WHO; 2006. Available at: https:// apps. who. int/ iris/ handle/10665/39478. Accessed on 28 May 2019. 
19. Yasmeen J, Qurieshi MA, Manzoor NA, Asiya W, Ahmad SZ. Community-based screening of cervical cancer in a low prevalence area of India: a cross sectional study. Asian Pac J Cancer Prev. 2010;11(1):231-4.

20. Arun R, Singh JP, Gupta SB. Cross-sectional study on visual inspection with acetic acid and pap smear positivity rates according to sociodemographic factors among rural married women of Bareilly (Uttar Pradesh). Indian J Community Med. 2018;43:86-9.

21. Ramesh N, Nihkil D, Thaddaeu V, Cathrin N. Screening for cervical dysplasia and reproductive tract infections among coffee plantation workers in Kodagu District, Karnataka, India. Int J Occupational Safety Health. 2014;4(2):1-4.

22. Shamima Y, Anindya M. A cyto-epidemiological study on married women in reproductive age group (15-49 years) regarding reproductive tract infection in a rural community of West Bengal. Indian $\mathbf{J}$ Public Health. 2012;56(3):204-9.

23. Mhaske M, Jawadekar SJ, Saundale SG. Study of association of some risk factors and cervical dysplasia/cancer among rural women. Nat Jour of Com Medicine. 2011;2(2):209-12.

24. Thumoju S, Divyakolu S, Bhopal T, Gowrishetty S, Fatima SS, Ahuja YR, Mohan V. Experiences from cervical cancer screening program conducted at low-resource areas in Telangana. Int $\mathbf{J}$ Med Public Health. 2018;8(3):112-5.

25. Sharma P, Rahi M, Lal P. A community-based cervical cancer screening program among women of Delhi using camp approach. Indian J Community Med. 2010;35(1):86-8.

Cite this article as: Vyas $\mathrm{PH}$, Dhadwe K, Shah HA, Dave HM, Shah AA. A community based study to determine incidence of cervical cancer and willingness of women to participate in cervical cancer screening program in Navsari, Gujarat, India. Int J Reprod Contracept Obstet Gynecol 2019;8:3954-8. 